\title{
Encapsulation of Gotu Kola Leaf (Centella asiatica) Flavonoid in Instant Powder Drink Using Maltodextrin
}

\author{
Satrijo Saloko ${ }^{1, *}$, Dody Handito ${ }^{1}$, Nurul Nur Aeni ${ }^{1}$ \\ ${ }^{I}$ Faculty of Food Technology and Agroindustry, Mataram University \\ *Corresponding author.Email: s_saloko@unram.ac.id
}

\begin{abstract}
One of the methods that can be used for making Gotu kola (Centella asiatica) instant powder drink is encapsulation using freeze-drying technique. In order to maintain the flavonoid compound, needed of coating material that functions as protection material, that is maltodextrin. This research aimed to find out the effect of maltodextrin concentration on the yield of Gotu kola's flavonoid encapsulation in an instant powder drink. The experimental design used Completely Randomized Design (CRD) for physicochemical parameters and used Completely Randomized Block (CRB) for organoleptic parameters, single factor; concentration of maltodextrin that consisted of $15 \% ; 30 \% ; 45 \% ; 60 \% ; 75 \%$ and $90 \%$. All treatments were replicated three times. The analysis was done using Analysis of Variance (ANOVA) at 5\% probability level. The significant results were further analyzed using Orthogonal Polynomial for chemical and physic parameters and using Duncan Multiple Range Test for organoleptic parameters. The observed parameters were flavonoid content, antioxidant activity, total soluble solid, encapsulation efficiency, microstructure, particle size and organoleptic (aroma and taste) using scoring scales. The result showed that the addition of maltodextrin gave significant result on flavonoid content, antioxidant activities, total soluble solid, encapsulation efficiency and organoleptic. The best treatment was the addition of $75 \%$ maltodextrin with $63.50 \%$ flavonoid content, $74.40 \%$ of antioxidant activity and $98.10 \%$ of encapsulation efficiency.
\end{abstract}

Keywords: encapsulation, flavonoid, freeze drying, gotu kola leaf, maltodextrin

\section{INTRODUCTION}

Modernization has changed the life patterns of today's society. An unhealthy lifestyle often becomes a factor in the increasing numbers of degenerative disease sufferers in our society. WHO data (World Health Organization) in 2011 shows that various degenerative diseases are included in the top ten causes of human deaths in the world (Budilaksono et al., 2014). This situation could occur due to the lack of food intake that contains antioxidants.

Apart from vegetables and fruit, antioxidants could also be obtained from herbal plants such as Gotu kola. Gotu Kola (Centella asiatica) is a wild plant that grows on plantations, fields, curbs, rice fields or in fields that are wet (Besung, 2009). The use of gotu kola in the society is still relatively minimal, even though gotu kola contains a number of nutrients and components of chemicals that have a nutrasetic or pharmacological effect. In the study of Sunarjo (2012), the provision of gotu kola extract reduced the MDA levels (Malondialdehyde) in white rats that were exposed to cigarette smoke. Gotu Kola contains bioactive ingredients such as amino acids, flavonoids, terpenoids and essential oils (Permatasari et al., 2013).

One of the nutraceutical effects comes from flavonoid compounds contained in Gotu kola leaves. Flavonoids are a group of phenolic compounds that are widely found in plant tissues that act as antioxidants (Redha, 2010). Flavonoid compounds are not stable against changes as an effect of oxidation, light and chemical changes, so when being oxidized, the structure will change and its function as an active ingredient will decrease and even disappear. Its solubility would become low as well (Handayani et al., 2008). Based on research conducted by Selawa et al., (2013), the determination of the total flavonoid content of binahong ethanol extract showed that the heating process could decrease the total flavonoid content for $15-78 \%$. Therefore, it is necessary to make an appropriate effort to protect the flavonoid content of Gotu kola leaves, one technique that could be used is encapsulation.

Encapsulation is a technique of entrapment of core material in a certain number of encapsulating materials. Encapsulation can protect food bioactive components such as antioxidants by creating barriers that benefit the encapsulated material (Praptiningsih et al., 2014). Encapsulation aims to protect active ingredients that are sensitive to damage due to oxidation, loss of nutrients, protect flavors, aromas, pigments and increase solubility. The right technique for encapsulation of Centella asiatica flavonoids is freeze-drying technique, that has the advantage of maintaining the quality of drying results, especially for heat sensitive products (Yulvianti et al., 2015)

In the encapsulation process, the selection of encapsulant materials is also very important because it influences the stability of the emulsion before drying, flowing power, physical stability and storage power after drying (Gardjito et al., 2006). Arabic Gum, maltodextrin and whey protein are several types of encapsulants that are often used. Maltodextrin is an encapsulant that is often recommended. Maltodextrin is a product of starch 
hydrolysis using acids and enzymes. Maltodextrin has a characteristic as a good encapsulant because it has a low viscosity and an ability to form emulsions (Gardjito et al., 2006). Maltodextrin has a high oxidation resistance properties as well (Purnomo et al., 2014).

Distribution of maltodextrin concentration affects the desired encapsulation results. A research conducted by Alfonsius et al., (2015) shows that making drinks of secang (Caesalpinia sappan L) wood powder with different maltodextrin concentrations (20 $\mathrm{g} ; 25 \mathrm{~g}$ and $30 \mathrm{~g}$ ) affects ash content, total phenolic, antioxidant activity, dissolution time and PCA test (Total Plate Figures), and the best overall the maltodextrin concentration is $25 \mathrm{~g}$.

Gotu kola leaves has the potential to be developed as an instant powder drink product. Instant powder drinks are in a great demand by the public because its price is quite affordable and easy to serve. Therefore, a study has been conducted on "Encapsulation of Centella asiatica Flavonoid Compounds in Instant Powder Drinks Using Maltodextrin". This study is expected to be an information regarding the utilization of Centella asiatica herbal plants, and the right concentration of maltodextrin that can be obtained against the results of encapsulation of Centella asiatica compounds in instant powder drinks.

\section{METHODS}

\section{a. Tools and Ingredients}

The materials used in this study include: gotu kola leaves obtained from plantations in the village of Rempek - North Lombok, mineral water brands Narmada, maltodextrin, aquades, methanol 96\% (pro analys), ethanol 96\% (pro analys), ethanol $96 \%$ (technical), 70\% antiseptic alcohol (technical), aluminum chloride $\left(\mathrm{AlCl}_{3}\right)$ (pro analys), quercetin (pro analys), potassium acetate (pro analys) and DPPH solution $0.5 \mathrm{mM}$ (pro analys).

The tools used in the study include: spoons, bowls, plates, small glasses, sealed containers, basins, trays, stainless steel knives, stainless steel scissors, wipes, tissues, masks, gloves, label paper, vacuum plastic, dark bottle packaging, aluminium foil, plastic wrap, mortar, cup glass, measuring cup, volumetric flask, volume pipette, drop pipette, micro pipette, glass preparation, stirring rod, test tube, effendorp tube, erlenmeyer, funnel, filter cloth, sieve , desiccator, shaker, stirrer, vortex, petri dish, Kern brand analytical scales, Kern brand digital scales, UV-Vis spectrophotometer Thermoscientific brand, Stuart SHM2 brand homogenizer, Philips brand blender, Modena brand freezer, Heidholp brand rotary evaporator, freeze dryer brand Martin Christ/Alpha 1.2 LD plus, Kruss brand handrefractometer, Olympus brand lab optical microscope, Hettich EBA 20 brand centrifuge and stationery.

\section{b. Preparation}

This study consisted of two stages of the process: the stage of extraction of gotu kola leaves and the stage of the process of encapsulation of the flavonoids of gotu kola leaves in instant powder drinks using maltodextrin.

\section{c. Extraction stage of Gotu Kola Leaves}

The extraction process of gotu kola is done by referring to the maceration method used by Lumbessy et al., (2013), with a modification in the use of $96 \%$ ethanol. Gotu kola leaves are sorted from stone, gravel, damage or wilt. Sorting results are washed with running water to remove impurities, then dried at room temperature for 24 hours. Gotu kola leaves weighed as much as $5,000 \mathrm{~g}$, then blended for about 2 minutes and added 25 liters of $96 \%$ ethanol while stirring occasionally. The maceration method is carried out for 24 hours. The results of maceration are filtered using a filter cloth. To get the Gotu kola extract, evaporation is then done using a rotary evaporator at $40^{\circ} \mathrm{C}$ until the solvent has evaporated. Gotu kola leaf extract obtained was analysed to determine the total flavonoid content.

\section{d. Encapsulation Process Stage}

In general, the encapsulation processesof instant powder drinks are often found in various literatures. According to Supriyadi et al. (2013), the stages of encapsulation process of Centella asiatica flavonoids in instant powder drinks was using the maltodextrin, which has been modified in the homogenization process and preliminary research as follows: Gotu kola leaf extract which has been analyzed for the determination of total flavonoids are dissolved using distilled water 1: 1 and add maltodextrin according to the treatment $(15 \% ; 30 \% ; 45 \% ; 60 \%$; $75 \%$ and $90 \%$ ). The mixture is homogenized using a homogenizer with a scale speed of 3 proportional to $4,500 \mathrm{rpm}$ for 5 minutes. Put it in a container and freeze it in the freezer at $25^{\circ} \mathrm{C}$. In the making of instant powder drinks, a drying method is needed, called freeze drying at $-50^{\circ} \mathrm{C}$ for 48 hours. The produced instant Gotu kola leaf powder drink then mashed up and sifted using an 80-mesh size sieve. Gotu kola instant powder drink then packed using dark bottle packaging.

\section{e. Preparation of Trial}

The experimental design used was Completely Randomized Design (CRD) for chemical quality parameters and physical quality parameters, and Randomized Block Design (RBD) for organoleptic quality parameters with a single factor experiment, namely the concentration of maltodextrin.

The maltodextrin concentration consisted of 6 treatments as follows:

M1 $=$ Maltodextrin of $15 \%$

M2 $=$ Maltodextrin of 30\%

M3 = Maltodextrin of $45 \%$

M4 $=$ Maltodextrin of $60 \%$

M5 $=$ Maltodextrin of $75 \%$

M6 $=$ Maltodextrin of $90 \%$

Based on the results of the calculation of the number of replications, then the accuracy was repeated 3 times to obtain 18 experimental units.Observationdata were analyzed using Analysis of Variance (ANOVA) at a real level of 5\% using Gen-Stat software. If it is significant, further testing is done using Orthogonal Polynomial test for chemical quality parameters and physical quality parameters and Duncan's advanced test for organoleptic quality parameters (Hanafiah, 2014).

\section{f. Analysis}

The analysis carried out in this study were: the analysis of total flavonoid content determination using aluminium chloride method and the making of a standard quercetin solution as a standard comparison using a UV-Vis spectrophotometer (Yulianti et al., 2014) referring to the procedure of Chang et al., 2002), analysis of antioxidant activity methods DPPH uses a UV-Vis spectrophotometer (Garcia et al., 2012), analysis of total dissolved solids by the hand refractometer method (Maslikhah, 2015), encapsulation efficiency analysis (Sukmawati et al., 2015), microstructure and particle size analysis using a lab optical microscope (Aulanni'am, 2012) and 
organoleptic scoring analysis of flavour and taste (Rahayu, 1998).

\section{RESULTS AND DISCUSSION}

\section{i. Chemical Quality}

The chemical quality parameters observed in this study included total flavonoid levels, antioxidant activity and total dissolved solids. Based on the diversity analysis, the addition of maltodextrin concentration had a significant effect on total flavonoid levels, antioxidant activity and total dissolved solids. The results of chemical quality and orthogonal polynomial tests can be seen in Table 1 and Figure 2.

\section{ii. Physical Quality}

The physical quality parameters observed in this study included encapsulation efficiency, microstructure and particle size. Based on the diversity analysis, the addition of maltodextrin concentration had a significant effect on encapsulation efficiency. The results of physical quality and orthogonal polynomial tests can be seen in Table 1 and Figure 2. The results of microstructure analysis and the statistical test of particle size are not done and can be seen in Figure 3.

\section{iii. Organoleptic Quality}

The organoleptic quality parameters observed in this study including the scoring test of flavor and taste. Based on diversity analysis, the addition of maltodextrin concentration had a significant effect on the scoring of taste and flavor. The average results and Duncan'sadvanced test can be seen in Table 2 and Figure 3.

Table 1. Purata and Advanced Orthogonal Polynomial Test Results on the Addition of Maltodextrin (M) Concentration to the Chemical Quality Parameters and Physical Quality Parameters.

\begin{tabular}{|c|c|c|c|c|}
\hline \multirow[b]{2}{*}{ Treat-ment } & \multicolumn{4}{|c|}{ Parameter } \\
\hline & $\begin{array}{c}\text { Flavonoid (\%) } \\
\pm \text { SD }\end{array}$ & $\begin{array}{c}\text { Antioxi-dant } \\
\text { Activity }(\%) \pm \text { SD }\end{array}$ & $\begin{array}{l}\text { Total Dissolved } \\
\text { Solid }(\%) \pm \text { SD }\end{array}$ & $\begin{array}{c}\text { Encapsu-lation } \\
\text { Efficiency }(\%) \pm \text { SD }\end{array}$ \\
\hline M1 (15\%) & $22.45 \pm 0.30$ & $41.76 \pm 0.33$ & $5.33 \pm 0.05$ & $34.68 \pm 0.47$ \\
\hline M2 (30\%) & $28.06 \pm 0.61$ & $44.66 \pm 0.38$ & $5.56 \pm 0.05$ & $43.35 \pm 0.94$ \\
\hline M3 (45\%) & $37.01 \pm 0.30$ & $53.98 \pm 0.19$ & $6.50 \pm 0.05$ & $57.18 \pm 0.46$ \\
\hline M4 (60\%) & $51.92 \pm 0.61$ & $58.69 \pm 0.39$ & $6.76 \pm 0$ & $80.21 \pm 0.94$ \\
\hline M5 (75\%) & $63.50 \pm 0.30$ & $74.40 \pm 0.33$ & $7.53 \pm 0.05$ & $98.10 \pm 0.47$ \\
\hline M6 $(90 \%)$ & $27.19 \pm 0.60$ & $51.73 \pm 0.51$ & $7.96 \pm 0.05$ & $42.00 \pm 0.93$ \\
\hline Linear & S & S & $\mathrm{S}$ & \\
\hline Quadratic & S & S & NS & \\
\hline
\end{tabular}

Table2. The Results of Purata and Duncan's Advanced Test on the Addition of Maltodextrin (M) Concentration to Organoleptic Quality Parameters

\begin{tabular}{|l|l|l|}
\hline \multirow{2}{*}{\multicolumn{1}{c|}{ Treatment }} & \multicolumn{1}{c|}{ Flavour \pm SD } & \multicolumn{1}{c|}{ Taste \pm SD } \\
\cline { 2 - 3 } & \multicolumn{1}{|c|}{ Parameter } \\
\hline M1 (15\%) & $1.72 \pm 0.71 \mathrm{~d}$ & $1.52 \pm 0.73 \mathrm{~d}$ \\
\hline M2 (30\%) & $2.24 \pm 0.91 \mathrm{c}$ & $2.44 \pm 0.66 \mathrm{c}$ \\
\hline M3 (45\%) & $2.32 \pm 1.13 \mathrm{c}$ & $2.96 \pm 0.74 \mathrm{~b}$ \\
\hline M4 (60\%) & $2.88 \pm 0.83 \mathrm{~b}$ & $3.12 \pm 0.83 \mathrm{~b}$ \\
\hline M5 (75\%) & $3.08 \pm 1.03 \mathrm{ab}$ & $3.36 \pm 0.81 \mathrm{ab}$ \\
\hline M6 (90\%) & $3.28 \pm 0.98 \mathrm{a}$ & $3.68 \pm 1.06 \mathrm{a}$ \\
\hline Duncan 5\% & 0.4042 & 0.4701 \\
\hline
\end{tabular}

Note: The numbers followed by the same letters in the same column are not significantly different at the $5 \%$ level.SD = Standard Deviation

\section{b. Discussion}

Below is the discussion of each parameter:

\section{$i$. The Total of Flavonoid Content}

The analysis of total flavonoid content determination in this study was carried out by making a standard curve or standard comparison using a standard solution of quercetin with concentrations of $0.0 ; 2.0 ; 4.0 ; 6.0 ; 8.0$ and $10.0 \mathrm{ppm}$. After that measure the absorbance using a UV-Vis spectrophotometer with a wavelength of $440 \mathrm{~nm}$. Based on the results of absorbance measurements, a standard quercetin curve can be drawn in the form of a graph of the curve of concentration (C) versus absorbance (A) and can be seen in Figure 1.

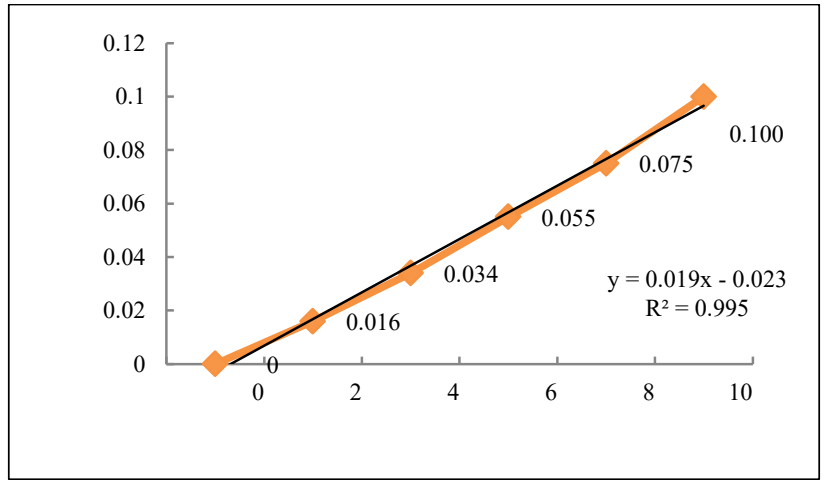

Figure 1. Quercetin Standard Solution Curve Graph 
Based on Figure 1, the regression equation value obtained $\mathrm{y}=$ $0.019 \mathrm{x}-0.023 . \mathrm{x}(\mathrm{C})$ is the concentration of quercetin $(\mathrm{mg} / \mathrm{mL})$ or the value of the initial flavonoid content and $y$ is the absorbance value. The quercetin standard solution curve was used to determine the total flavonoid content contained in the instant beverage of Gotu kola leaves through a regression equation and expressed in units of $\mathrm{mg}$ equivalent to quercetin $/ \mathrm{g}$ extract ( $\mathrm{mg} \mathrm{QE} / \mathrm{g}$ extract). The flavonoid content of instant Gotu kola leaves calculated with a predetermined calculation formula.

Based on Figure 2a, it shows that the regression pattern occurs quadratically with the equation $y=-3.555 x^{2}+29.02 x-9.318$ with a coefficient of determination $\mathrm{R} 2=0.593$. Because the value is negative, the quadratic equation $y=9.318+29.02 x-$ $3.555 \mathrm{x}^{2}$ is used, the quadratic equation can produce an estimation of the optimum value of total flavonoid content of Gotu kola leaf instant beverage by means of differentiation of equations. The result of differentiation produces the equation $y$ $=29.02-2(3.555) \mathrm{x}$ or $\mathrm{y}=29.02-7.11 \mathrm{x}$. Estimation of the optimum value is obtained if the value of $y$ (total flavonoid content) $=0=29.02-7.11 \mathrm{x}$, so that the value of $\mathrm{x}$ (concentration of maltodextrin) $=4.08$ is obtained. In this study, the addition of maltodextrin concentration has a range of $15 \%$ in each treatment. Thus, the estimation of the optimum value of total flavonoid content of Gotu kola leaf instant beverage was obtained when the addition of maltodextrin
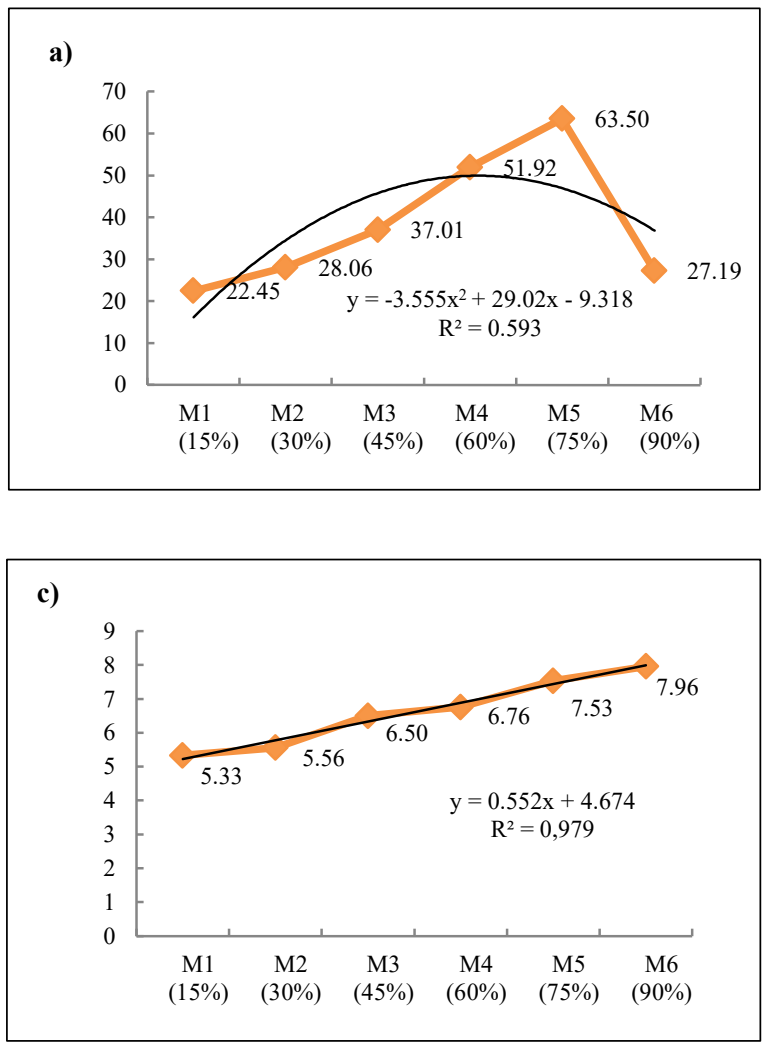

concentration was $4.08 \times 15 \%$ is $61.2 \%$. The value of correlation coefficient is obtained by rooting the coefficient of determination, so that the correlation coefficient value of 0.770 is included in the strong category. The coefficient of determination (KD) 0.593 means that $59.3 \%$ of the total flavonoids content of gotu kola leaf powder is influenced by the addition of the concentration of maltodextrin.

The increase in total flavonoid levels in the beverage of instant gotu kola leaf powder along with the increasing concentration of maltodextrin was caused by the use of maltodextrin encapsulation materials which have high oxidation resistance properties (Purnomo et al., 2014), its ability to shape the body (Srihari et al., 2010), and protect and control the release of active ingredients (Palupi et al., 2014). In addition, processing technology has an important role in the presence of flavonoid compounds. The processing technology used in this study was encapsulation by freeze-drying method.

Encapsulation technology using freeze-drying is recommended to be used to maintain flavonoid compounds. According to Praptiningsih et al. (2014), the principle of encapsulation aims to protect active ingredients that are sensitive to damage due to oxidation, loss of nutrients, protect flavour, aroma, pigment and increase solubility. Freeze drying is a drying technique that use a low temperature and vacuum pressure and thus has the advantage to maintain the quality of the drying results, especially for heat sensitive products.
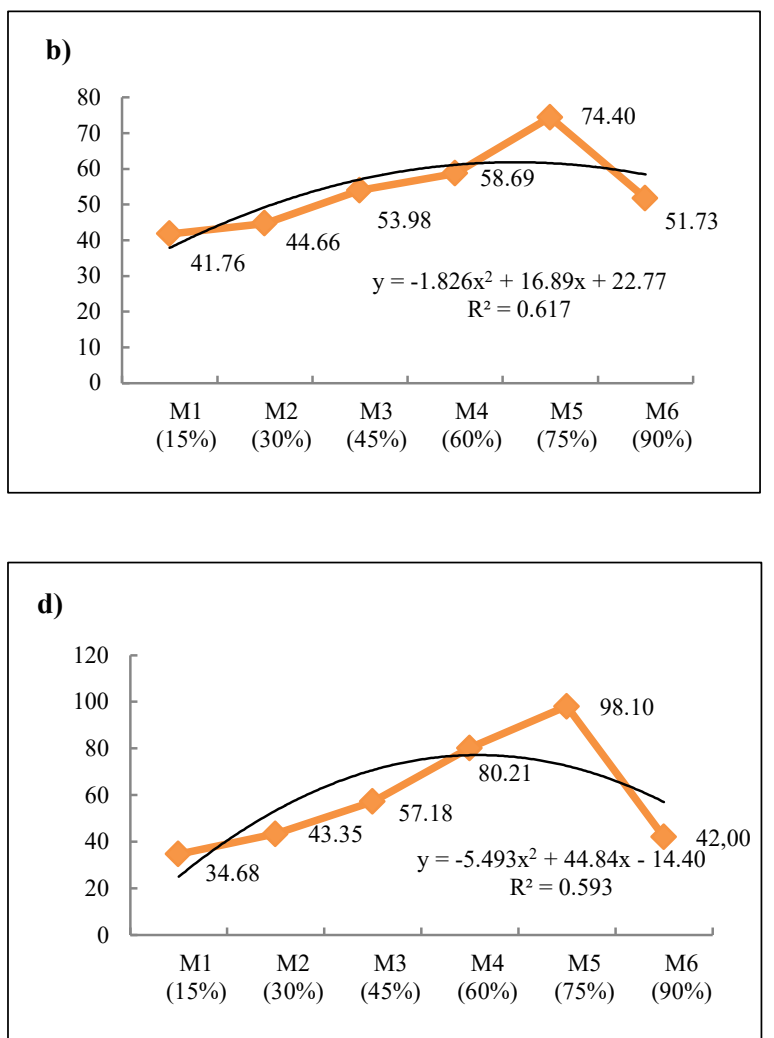

Figure 2. Graph of The Effect of Maltodextrin Concentration on Gotu Kola Leaf Powder Drinks on a) Total Flavonoid; b) Antioxidant Activitiy; c) Total Dissolved Solids; and d) Encapsulation Efficiency.

The decrease in the total flavonoid content of gotu kola leaf instant drink on the addition of M6 maltodextrin concentration $(90 \%)$ was caused by the excessive number of solids contained in the beverage of instant Gotu kola leaf powder, namely maltodextrin as encapsulant material. Maltodextrin is white, while the measurement of total flavonoid content determination 
was using a UV-Vis spectrophotometer and measure the intensity of the colour. Therefore, the colour intensity in the instant beverage of Gotu kola leaves with too much maltodextrin tends to decrease and the color measured by the $\mathrm{UV}$-Vis spectrophotometer is too low. The concentration of maltodextrin that is too high will complicate the process of encapsulation of flavonoids, and thus, many flavonoid compounds that come out are not encapsulated, and has the possibility to undergo chemical changes.

Total flavonoids levels are closely related to the antioxidant activity. According to Redha (2010),flavonoids are a group of phenolic compounds found in plant tissue that could act as an antioxidant. Thedecreasing number of total flavonoids content in instant Gotu kola leaf drink, could decrease the antioxidant activity of drinking instant Gotu kola leaf powder as well.

\section{ii. Antioxidant Activitiy}

Antioxidants in the chemical field means electron-giving compounds. Meanwhile, antioxidant activity is a compound activity that is able to capture the occurrence of free radical formation (Moein et al., 2007).

Figure $2 \mathrm{~b}$ shows that the regression pattern occurs quadratically with the equation $y=-1.826 x^{2}+16.89 x+22.77$ with a coefficient of determination $\mathrm{R} 2=0.617$. Since the value is negative, the quadratic equation $y=22.77+16.89 x-1.826 x^{2}$ is used, the quadratic equation can produce an estimation of the optimum value of antioxidant activity for Gotu kola leaf instant drink by differentiating equations. The result of differentiation produces the equation $\mathrm{y}=16.89-2(1,826) \mathrm{x}$ or $\mathrm{y}=16.89-$ $3.65 \mathrm{x}$. Estimation of the optimum value is obtained if the $y$ value (antioxidant activity) $=0=16.89-3.65 \mathrm{x}$, so that the value of $\mathrm{x}$ (maltodextrin concentration) $=5.06$ is obtained. In this study, the addition of maltodextrin concentration has a range of $15 \%$ in each treatment, so that the estimation of the optimum value of antioxidant activity for instant gotu kola leaf powder drinks was obtained when the addition of maltodextrin concentration was $5.06 \times 15 \%$ is $75.9 \%$. The value of correlation coefficient is obtained by rooting the coefficient of determination so that the correlation coefficient value of 0.875 is included in the very strong category. The coefficient of determination 0.617 means that $61.7 \%$ of antioxidant activity in the beverage of instant Gotu kola leaves is influenced by the addition of the concentration of maltodextrin.

The increase of antioxidant activity in the Gotu kola leaf instant beverage along with the increasing concentration of maltodextrin was caused by the use of maltodextrin encapsulation materials, that contains high oxidation resistance properties (Purnomo et al., 2014), that has the ability to form bodies (Srihari et al., 2010), protect and control the release of active ingredients (Palupi et al., 2014). In addition, processing technology has an important role to play on antioxidant activity compounds in processed foods. The processing technology used in this study was encapsulation using freeze drying. According to Praptiningsih et al. (2014), encapsulation is able to protect food bioactive components such as antioxidants by creating a barrier that is beneficial for the encapsulated material. Freeze drying is a drying technique using low temperature and vacuum pressure, and thus maintaining the quality of the drying results, especially for the heat sensitive products.

This research is in accordance with Yusilawati (2016), showing that freeze drying causing the antioxidant activity to increase along with the addition of maltodextrin concentration in the instant powder of red dragon fruit skin. The research of Yuliawaty et al. (2015), shows that using oven drying, antioxidant activity tends to decrease along with the addition of the concentration of maltodextrin in noni leaf instant drink, this is because the heat causes the phenol compound to decompose, therefore its ability as an antioxidant decrease. The advantage of freeze drying compared to other drying methods is that it does not cause wrinkles, more porous surface, lower density, easily refreshed, normal colour, better flavour quality and more nutritional value can be maintained (Hariyadi, 2013).

Reduction in the antioxidant activity of instant Gotu kola leaf powder drinks in addition to the concentration of M6 maltodextrin $(90 \%)$ due to the excessive number of solids contained in the beverage of instant Gotu kola leaf powder namely maltodextrin as encapsulant material. Maltodextrin is white, while the measurement of antioxidant activity using a $\mathrm{UV}-\mathrm{Vis}$ spectrophotometer is by measuring the intensity of the colours in the instant gotu kola leaf powder drink. Therefore, the colour intensity in the instant beverage of Gotu kola leaf with too much maltodextrin tends to decrease, therefore the color measured by the UV-Vis spectrophotometer is too low.

\section{iii. Total Dissolved Solid}

The total dissolved solids referred in this study is the presence of dissolved material in a solution of instant beverage of gotu kola leaf.

Figure $2 \mathrm{c}$ shows that the regression pattern occurs linearly with the equation $\mathrm{y}=0.552 \mathrm{x}+4.674$ with a coefficient of determination $\mathrm{R}^{2}=0.979$. The value of $0.552 \mathrm{x}$ determines the direction of linear regression. Because the value is positive, this shows a positive relationship, meaning that the increase in the addition of the concentration of maltodextrin causes an increase in the total dissolved solids of the Gotu kola leaf instant drink by $0.522 x$. The value of correlation coefficient is obtained by rooting the coefficient of determination so that the correlation coefficient value of 0.989 is included in the very strong category. The coefficient of determination 0,979 means that $97.9 \%$ of the total dissolved solids are affected by the addition of the concentration of maltodextrin.

The increase in total dissolved solids of instant Gotu kola leaf drink along with the increasing concentration of maltodextrin because maltodextrin is basically an imperfect hydrolysis of starch compounds called partial hydrolysis which consists of a mixture of sugars in simple form (mono and disaccharide) in small amounts, oligosaccharides with a relatively high number of short chains and a small number of long-chain oligosaccharides (Chafid et al., 2010). In addition, the properties possessed by maltodextrin include rapid dispersion, high solubility properties.

According to Yulianti et al. (2014), the components measured as total dissolved solids are sucrose, reducing sugars, organic acids and proteins. Therefore, the higher the concentration of 
maltodextrin, the greater the amount of simple sugars in it, so the sugars will dissolve in water. This study is in accordance with the research of Srihari et al. (2010), that said: a solution containing a lot of dissolved solids has a greater total value of dissolved solids than a solution containing less dissolved solids.

\section{iv. Encapsulation Eficiency}

The encapsulation efficiency in this study was used to measure the success of the encapsulation process of Centella asiatica flavonoids in instant powder drinks using maltodextrin.

Figure $2 \mathrm{~d}$ shows that the regression pattern occurs quadratically with the equation $y=-5.493 \mathrm{x}^{2}+44.84 \mathrm{x}-14.40$ with a coefficient of determination $\mathrm{R}^{2}=0.593$. Because the value is negative, the quadratic equation $\mathrm{y}=14.40+44.84 \mathrm{x}-5.493 \mathrm{x}^{2}$ is used, the quadratic equation can produce an estimation of the optimum value of the encapsulation efficiency of Gotu kola leaf instant beverage by differentiating equations. The results of differentiation produce the equation $\mathrm{y}=44,84-2(5,493) \mathrm{x}$ or $\mathrm{y}$ $=44,84-10,98 \mathrm{x}$. Estimation of the optimum value is obtained if the $y$ value (encapsulation efficiency) $=0=44.84-10.98 \mathrm{x}$, so that the value of $\mathrm{x}$ (maltodextrin concentration) $=4.08$. In this study, the addition of maltodextrin concentration has a range of $15 \%$ in each treatment, so the estimation of the optimum value of the encapsulation efficiency of gotu kola leaf instant beverage was obtained when the addition of maltodextrin concentration was $4.08 \times 15 \%$ is $61.2 \%$. The value of correlation coefficient is obtained by rooting the coefficient of determination, so that the correlation coefficient value of 0.770 , which is included in the strong category. The coefficient of determination 0.593 means that $59.3 \%$ of the efficiency of the encapsulation of the beverage for instant Gotu kola leaves is influenced by the addition of the concentration of maltodextrin.

Encapsulation efficiency is where a lot of active substances trapped rather than the total active substance in the capsule (Carneiro et al., 2012), therefore, total flavonoid compounds do not affect the efficiency of encapsulation, but that affects the number of encapsulated flavonoid compounds. Flavonoid content of Gotu kola extract or before the encapsulation process was $64.73 \%$. Increasing the efficiency of encapsulation of Gotu kola leaf instant drink along with the increasing concentration of maltodextrin due to the properties possessed by maltodextrin informing the body (Srihari et al., 2010), so that many flavonoid compounds are encapsulated. In addition, the freezedrying technique is a drying technique using low temperatures, thus helpto maintain flavonoid compounds against chemical changes.

The decreasing efficiency of the encapsulation of Gotu kola leaf instant drink on the addition of the concentration of maltodextrin M6 (90\%) was caused by too much total solids contained in the beverage of instant gotu kola leaf powder, namely maltodextrin as an encapsulant material. Too much maltodextrin concentration will complicate the process of encapsulation of flavonoid compounds so that many flavonoid compounds were released and not encapsulated. Sukmawati et al. (2015), states that it is necessary to pay attention to the optimum amount of encapsulant material used to obtain high encapsulation efficiency.
This research is in accordance with Nurlaili et al. (2014), that showed the efficiency of encapsulation of ginger pulp oleoresin decreased along with the increasing concentration of encapsulated materials used. This is because of the more solids in the emulsion, the higher the viscosity. Rosenberg et al. (1985), explains that the emulsion viscosity that is too much will actually reduce the value of encapsulation efficiency.

\section{v. Microstructure and Particle Size}

The microstructure analysis and particle size of the instant beverage Gotu kola leaves in this study were carried out directly using a lab optical microscope that was connected to the computer at a $20 \mathrm{x}$ magnification. In general, spherical particles are irregular. The particle size of the instant powder of Gotu kola leaves has a particle size with range of 18.70-38.60 $\mu \mathrm{m}$ and tend to increase along with the increase of the concentration of maltodextrin (figure not shown). This is probably due to an imperfect homogenization process. In this study homogenization used the same speed and time so that maltodextrin with Gotu kola leaf extract was not completely dissolved by increasing the concentration of maltodextrin. According to Saloko (2013), the homogenization process of liquid smoke nano-encapsulation which includes homogenization temperature, homogenizer speed and homogenization time plays an important role during the treatment process because it affects the size of the particles produced.

Gotu kola instant powder drinks are included in microencapsulation which usually has a particle size ranged rom 20-5000 $\mu \mathrm{m}$ (Zuidam et al., 2010). The smaller the particle size of instant gotu kola leaf powder, the easier it will be to dissolve in water.

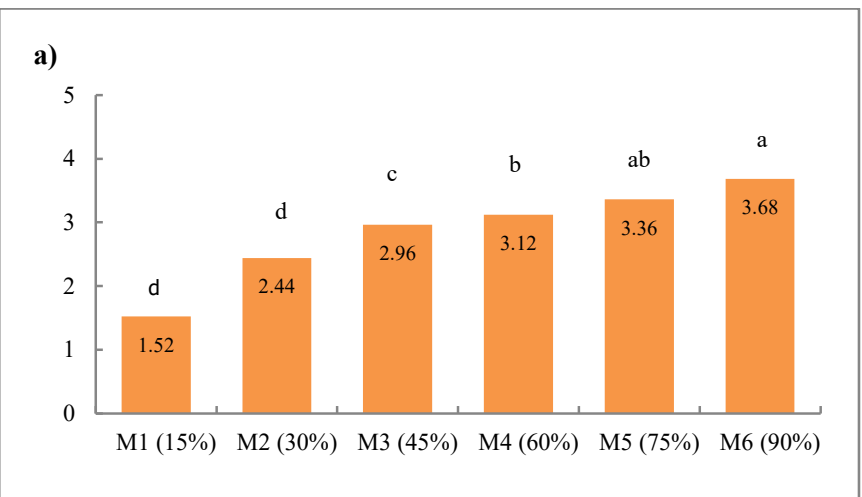

b)

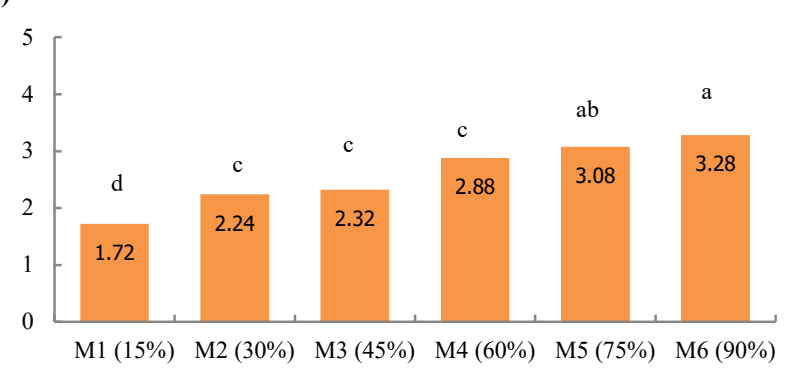

Figure 3. Graph The Effect of Maltodextrin Concentration on Gotu Kola Leaf Powder Drinks on a) Aroma; and b)Taste 


\section{vi. Aroma (Scoring)}

The aroma is an indicator to determine the level of customer acceptance of a product. Figure $3 \mathrm{a}$ shows that the organoleptic results of the aroma (scoring) of Gotu kola leaves instant drink have a range of values from 1.52 (scented with Gotu kola leaves) to 3.68 (somewhat unflavored Gotu kola leaves). This shows that the addition of maltodextrin concentration can retain the aroma of Gotu kola leaf beverage to a degree that is not as scented as gotu kola leaves. This is due to the absence of flavour enhancements in the manufacture of Centella asiatica instant powder drinks. In addition, the encapsulation method using the freeze-drying technique has advantages in maintaining the bioactive flavonoid compounds found in instant Gotu kola leaf powder drinks.

Flavonoid compounds are included in phenolic compounds, which are secondary plant metabolites and important components in sensory quality and nutrition of fruits, vegetables and other plants (Tomas et al., 2000). Therefore, the scent of Centella asiatica leaves was caused by the flavonoid compounds contained in the instant Gotu kola leaf powder drinks.

The higher the concentration of maltodextrin, the lower the aroma of instant powder drink of Gotu kola leaves, due to the bland aroma of maltodextrin which affects the aroma of Gotu kola leaves. The aroma of instant Gotu kola leaf powder drink is in accordance with the quality requirements of traditional beverage powder according to SNI 01-4320-1996, which has a distinctive aroma of spices, based on the aroma of its main raw material.

\section{vii. $\quad$ Taste (Scoring)}

Taste scoring is one of the most important factors in determining the taste of food. Based on Figure 3b, the average organoleptic taste (scoring) of instant Gotu kola leaves has a range values of 1.72 (flavoured Gotu kola leaves) to 3.28 (rather like Gotu kola leaves). This shows that the addition of maltodextrin concentrations were able to maintain the taste of Gotu kola leaf instant drink. This was caused by the absence of flavour enhancements in the production of Centella asiatica instant powder drinks. In addition, the encapsulation methods using the freeze-drying technique has advantages in maintaining the bioactive flavonoid compounds found in instant gotu kola leaf powder drinks. Flavonoid compounds are included in phenolic compounds which are secondary plant metabolites and one of the most important components in sensory quality and nutrition of fruits, vegetables and other plants (Tomas et al., 2000).

The higher the concentration of maltodextrin, the lower the taste of instant drink of Gotu kola leaves, caused by the maltodextrin compound that has a sweet taste and affects the taste of Gotu kola leaves itself. The taste of the Gotu kola leaf instant drink is in accordance with the quality requirements of traditional beverage powder drink according to SNI 01-43201996, which has a distinctive taste of spices or according to the taste of the main raw material.

\section{CONCLUSION}

Based on the analysis, results, and discussion it can be concluded that the addition of maltodextrin concentration in the encapsulation process of Gotu kola leaf flavonoids in instant powder drinks using maltodextrin had a significant effect on the flavonoid levels, antioxidant activity, total dissolved solids, encapsulation efficiency, organoleptic aroma and organoleptic taste scoring.

The addition of maltodextrin concentration M5 (75\%) was the best result seen from the parameters of total flavonoid levels of $63.50 \%$, antioxidant activity of $74.40 \%$ and encapsulation efficiency of $98.10 \%$. Based on the results of the quadratic equation obtained, the optimum estimation value of the maltodextrin concentration to the flavonoid level was $61.2 \%$, to the antioxidant activity was $75.9 \%$ and the encapsulation efficiency was $61.2 \%$

\section{REFERENCES}

[1] A.N.S. Thomas., Tanaman Obat Tradisional. I.RD 13. Kanisius. Yoyakarta. 2000.

[2] Alfonsius., Pranata, S., and Purwijantiningsih, E, Kualitas Minuman Serbuk Instan Kayu Secang (Caesalpinia sappan L.) dengan Variasi Maltodekstrin. Laporan Penelitian. Fakultas Teknobiologi. Universitas Atmajaya. 2015

[3] Aulanni'am, Instruksi Kerja Pemakaian Mikroskop. Program Kedokteran Hewan. Universitas Brawijaya. 2012.

[4] Besung, I.N.K.,. Pegagan (Centella asiatica) Sebagai Alternatif Pencegahan Penyakit Infeksi pada Ternak. Buletin Veteriner Udayana. Vol. 1 No. 2. :61-67. 2009

[5] Budilaksono, W., Wahdaningsih, S., dan Fahrurroji, A. Uji Aktivitas Antioksidan Fraksi N-Heksana Kulit Buah Naga Merah (Hylocereus lemairel Britton and Rose) Menggunakan Metode DPPH (1,1-difenil-2pikrilhidrazil). Laporan Penelitian. Fakultas Kedokteran. Universitas Tanjungpura. 2014.

[6] Carneiro, H.C.F., Tonon, R.V., Grosso, C.R.F., and Hubinger, M.D., Encapsulation Efficiency and Oxidative Stability of Flaxseed Oil Microencapsulated By Spray Drying Using Different Combinations Of Wall Material. Journal of Food Engineering. 2012.

[7] Chafid, A., dan Kusumawardhani, G., Modifikasi Tepung Sagu Menjadi Maltodekstrin Menggunakan Enzim $\alpha$-amilase. Skripsi. Jurusan Teknik Kimia. Fakultas Teknik. Universitas Diponegoro Semarang. 2010.

[8] Chang, C.C., Yang, M.H., Wen, H.M., and Chern, J.C. Estimation of Total Flavonoid Content in Jurnal Fitofarmaka Indonesia, Vol. 1 No.1 18 Propolis By Two Complementary Colorimetric Methods. J Food Drug Ana. $10: 178-182.2002$.

[9] Garcia, E.J., Oldoni, T.LC., Alencar, S.M., Reis, A., Loguercio, A.D., and Grande, R.H.M., Antioxidant Activity By DPPH Assay of Potential Solution to be Applied on Bleached Teeth. Braz Dent Journal (2012) 23(1): 22-27. 2012.

[10] Gardjito, M., Murdiati, A., dan Aini, N., Mikroenkapsulasi $\beta$-Karoten Buah Labu Kuning dengan Enkapsulan Whey dan Karbohidrat. Laporan Penelitian. Fakultas Teknologi Petanian dan Fakultas Pertanian. Universitas Gadjah Mada dan Universitas Jendral Soedirman. 2006.

[11] Hanafiah, K.A., Rancangan Percobaan Teori dan Aplikasi (Edisi 3). PT. Raja Grafindo Persada. Jakarta. 2014.

[12] Handayani, R., dan Sulistyo, J., Sintesis Senyawa Flavonoid- $\alpha-G$ likosida Secara Reaksi Transglikosilasi 
Enzimatik dan Aktivitasnya Sebagai Antioksidan. Biodiversitas. Vol. 9 No. 1. Hal 1-4. 2008.

[13] Hariyadi, P., Freeze Drying Technology: for Better Quality and Flavor of Dried Products. Foodreview Indonesia. Vol. VIII No. 2. 2013.

[14] Lumbessy, M., Abidjulu, J., dan Paendong J.J.E., Uji Total Flavonoid pada Tanaman Obat Tradisional di Desa Waitina Kecamatan Mangoli Timur Kabupaten Kepulauan Sula Provinsi Maluku Utara. Jurnal MIPA Unsrat Online 2(1) 50-55. 2013.

[15] Maslikhah, F., Teknologi Pembuatan Bubur Jamur Merang (Volvariella volvaceae) Terfermentasi. Skripsi. Fakultas Teknologi Pertanian. Universitas Jember. 2015.

[16] Nurlaili, F.A., Darmadji, P., dan Pranoto Y., Mikroenkapsulasi Oleoresin Ampas Jahe (Zingiber Officinale Var.Rubrum) dengan Penyalut Maltodekstrin. Agritech. Uiversitas Gajah Mada. Vol. 34 No. 1. 2014.

[17] Palupi, N.W., Setiadi, P.K.J., dan Yuwanti, S. Enkapsulasi Cabai Merah dengan Teknik Coacervation Menggunakan ALginat yang Disubstitusi Tapioka Terfotooksidasi. Jurnal Aplikasi Teknologi Pangan 3 (3). 2014.

[18] Permatasari, S.M.E., Purwadi., dan Thohari, I. Pengaruh Penambahan Gelatin Sebagai Enkapsulan Ekstrak Pegagan (Centella asiatica) Terhadap Kadar Air, Kadar Abu, Kelarutan dan Rendemen. Laporan Penelitian. Fakultas Peternakan. Universitas Brawijaya.

[19] Praptiningsih, Y., dan Palupi, N.W., Aplikasi Tapioka Teroksidasi pada Enkapsulasi Antioksidan dari Ampas Seduhan Kopi dengan Teknik Coacervartion. Penelitian Hibah Bersaing. Universitas Jember. 2014.

[20] Purnomo, Wahyu., Khasanah, L.U., dan Anandito, R.B.K., 'Pengaruh' Ratio Kombinasi Maltodekstrin, Karagenan dan Whey Terhadap Karakteristik Mikroenkapsulan Pewarna Alami Daun Jati (Tectona grandis L. f.). Jurnal Aplikasi Teknologi Pangan 3(3). Universitas Sebelas Maret. 2014.

[21] Rahayu, W.P., Penilaian Organoleptik. Fakultas Teknologi Pertanian. Institut Pertanian Bogor: Bogor. 1998.

[22] Redha, A., Flavonoid: Struktur, Sifat Antioksidatif dan Peranannya dalam Sistem Biologis. Jurnal Belian. Vol. 9 No. 2 :196-202. 2010.

[23] Rohyami, Y., Penentuan Kandungan Flavonoid dan Ekstrak Metanol Daging Buah Mahkota Dewa (Phaleria macrocarfa Scheff Boerl). Jurnal Logika. Vol. 5 No. 1. 2008.

[24] Rosenberg, M., Kopelman, I.J., and Talmon, Y., Scanning ElektronMicroscopy Study of Microencapsulation. Journal of Food Sience 50: 113844. 1985.

[25] Saloko, S., Nanoenkapsulasi Asap Cair dalam Kitosan dan Maltodekstrin menggunakan Teknik Spray Drying. Disertasi. Universitas Gadjah Mada Yogyakarta. 2013.

[26] Selawa, W., Runtuwene, M.R.J., dan Citraningtyas, G., Kandungan Flavonoid Dan Kapasitas Antioksidan Total Ekstrak Etanol Daun Binahong (Anredera cordifolia (Ten.) Steenis). Jurnal Ilmiah Farmasi-UNSRAT. Vol. 2 No. 01. 2013.

[27] Srihari, E., Lingganingrum F.S., Hervita, R., dan Wijaya, H., Pengaruh Penambahan Maltodekstrin Pada Pembuatan Santan Kelapa Bubuk. Seminar Rekayasa Kimia dan Proses. Fakultas Teknik. Universitas Surabaya. 2010.

[28] Standar Nasional Indonesia, Serbuk Minuman Tradisional.

http://sisni.bsn.go.id/index.php?/snimain/sni/detailsni/4 766. (Diakses 23 Maret 2016). 1996.

[29] Sukmawati, A., Yuliani, R., Wahyuni, A.S., Lisdayanti., dan Listyaningrum, S., Formulasi dan Evaluasi Mikropartikel Dexamethasone Lepas Lambat dengan Matriks Ethyl Cellulose. University Research Colloquium. 2015.

[30] Sunarjo, I., Pemberian Ekstrak Pegagan (Centella asiatica) Menurunkan Kadar Mda Tikus Putih (Wistar) yang Dipapar Asap Rokok. Tesis. Program Studi Ilmu Biomedik. Universitas Udayana. 2012.

[31] Supriyadi dan Rujita, A.S., Karakteristik Mikrokapsul Minyak Atsiri Lengkuas dengan Maltodekstrin Sebagai Enkapsulasi. J. Teknol dan Industri Pangan. Vol. 24 No. 2. 2013.

[32] World Health Organization, The 10 Leading Causes of Death in The World, 2000 and 2011. (Online). (http://www.who.int/ mediacentre/ factsheets fs310/en/index.html. (Diakses 07 Maret 2016). 2013.

[33] Yulianti, D., Susilo, B., dan Yulianingsih, R., Pengaruh Lama Ekstraksi dan Konsentrasi Pelarut Etanol Terhadap Sifat Fisika-Kimia Ekstrak Daun Stevia (Stevia Rebaudiana Bertoni M.) dengan Metode Microwave Assisted Extraction (Mae). Jurnal Bioproses Komoditas Tropis. Vol. 2 No. 1. Universitas Brawijaya. 2014.

[34] Yulianti, R., Dahlia, A., dan Ahmad, A.R., Penetapan Kadar Flavonoid Total dari Ekstrak Etanolik Daun Benalu Mangga (Dendrophthoe Pentandra L. Miq). Jurnal Fitofarmaka Indonesia. Vol. 1 No.1. 2014.

[35] Yuliawaty, S.T., dan Susanto, W.H., Pengaruh Lama Pengeringan dan Konsentrasi Maltodekstrin Terhadap Karakteristik Fisik Kimia dan Organoleptik Minuman Instan Daun Mengkudu (Morinda Citrifolia L). Jurnal Pangan dan Agroindustri Vol. 3 No 1. Universitas Brawijaya. 2015.

[36] Yulvianti, M., Ernayati, W., Tarsono., dan M. Alfian R., Pemanfaatan Ampas Kelapa Sebagai Bahan Baku Tepung Kelapa Tinggi Serat dengan Metode Freeze Drying. Jurnal Integrasi Proses. Vol. 5 No. 1 :101-107. 2015.

[37] Yusilawati, Pengaruh Konsentrasi Maltodekstrin Terhadap Karakteristik Serbuk Kulit Buah Naga Merah (Hylocereus costarinces) Menggunakan Teknik Freeze Drying. Skripsi. Universitas Mataram. 2016.

[38] Zuidam, N.J., and Shimoni, E., Overvie of Microencapsulates for Use in Food Products or Processses and Methods to Make Them. Review. Springer Science+Business Media. 2010. 